\title{
Pengembangan Media Pembelajaran Berbasis Aplikasi Smartphone Untuk Memfasilitasi Kemampuan Berpikir Kreatif Matematis Siswa
}

\author{
Yuyun Suria Priangga \\ MAN 1 Kota Pekalongan, Jl. Bina Griya Raya No.64 Medono, Kec. Pekalongan Bar, Kota Pekalingan \\ yuyun.suria.priangga@gmail.com
}

\begin{abstract}
This study aims to see the steps to develop learning media based on smartphone applications in order to improve students' creative thinking skills. The development method uses ADDIE (analysis, design, development, implementation and evaluation). The implementation of learning media uses the Problem Based Learning (PBL) approach model assisted by a smartphone application. The initial analysis of the development of instructional media uses analysis of the needs and facts of learning media. Data processing uses quantitative approach data obtained from tests of students' creative thinking skills and the feasibility of learning media. Assessment of creative thinking skills based on aspects of fluency, flexibility, elaboration and authenticity of student problem management. The feasibility test of learning media is obtained from the validation of learning media and validation of learning materials. The research subjects were students of class X MAN 1 Kota Pekalongan with trigonometry material. The results of the evaluation were by comparing two class samples, the experimental class applied PBL assisted by a smartphone application and the control class applied PBL with the normal group discussion approach. The research resulted in (1) steps to develop instructional media, (2) the average result of students' mathematical creative thinking abilities in the experimental class which was higher than the control class.
\end{abstract}

Keywords: Development Media, ADDIE, Smartphone, Mathematical Creative Thinking Ability

\begin{abstract}
Abstrak
Penelitian ini bertujuan untuk mengetahui langkah pengembangan media pembelajaran berbasis aplikasi smartphone guna memfasilitasi kemampuan berpikir kreatif matematis siswa. Metode pengembangan menggunakan ADDIE (analisis, desain, development, implementasi dan evaluasi). Implementasi media pembelajaran menggunakan pendekatan model Problem-Based Learning (PBL) berbantuan aplikasi smartphone. Analisis awal pengembangan media pembelajaran menggunakan analisis kebutuhan dan ketersediaan media pembelajaran. Pengolahan data menggunakan pendekatan data kuantitatif yang didapat dari uji kemampuan berpikir kreatif matematis siswa dan uji kelayakan media pembelajaran. Penilaian kemampuan berpikir kreatif berdasarkan aspek kelancaran, keluwesan, elaborasi dan keaslian pemecahan masalah siswa. Uji kelayakan media pembelajaran didapat dari validasi media pembelajaran dan validasi materi pembelajaran. Subjek penelitian adalah siswa kelas X MAN 1 Kota Pekalongan materi trigonometri. Hasil evaluasi dengan cara membandingkan dua sampel kelas, kelas ekperimen dengan menerapkan PBL berbantuan aplikasi smartphone dan kelas kontrol menerapkan PBL dengan pendekatan diskusi grup normal. Penelitian menghasilkan (1) pengembangan media pembelajaran, (2) hasil rata-rata kemampuan berpikir kreatif matematis siswa kelas eksperimen lebih tinggi dari pada kelas kontrol.
\end{abstract}

Keywords: Pengembangan Media Pembelajaran, ADDIE, Smartphone, Kemampuan Berpikir Kreatif Matematis

Copyright (c) 2021 Yuyun Suria Priangga

$\square$ Corresponding author: Yuyun Suria Priangga

Email Address: yuyun.suria.priangga@gmail.com (Jl. Kalimantan No 37, Jember)

Received 21 April 2021, Accepted 25 April 2021, Published 26 April 2021

\section{PENDAHULUAN}

Pendidikan pada masa modern ini memiliki arti yang sangat luas, makna pendidikan sendiri saat ini terus berkembang mengikuti perkembangan zaman. Perkembangan dunia pendidikan dipengaruhi oleh faktor kebutuhan akan adaptasi di zaman modern, oleh karena itu perkembangan pendidikan selaras dengan perkembangan teknologi. Dalam konteks pembelajaran modern ditingkat manapun sudah akrab dengan teknologi, yang artinya masyarakat sudah memiliki dasar-dasar paham atas pemanfaatan 
teknologi dalam dunia pendidikan. Namun sangat disayangkan perkembangan dunia pendidikan di Indonesia ini sangat minim sekali dikembangkan. Menurut penelitian yang dilakukan NCTM (National Council of Teachers of Mathematics) salah satu permasalah dalam dunia pendidikan berkaitan dengan Technology Resources, yaitu pemanfaatan dan pengembangan teknologi yang sangat minim dilakukan oleh guru matematika. Pendidikan modern yang dimasud adalah penggunaan teknologi dan media audio visual sebagai media pembelajaran.

Melihat pada hasil penelitian yang dilakukan terhadap penggunaan media pembelajaran pendahulu, mengatakan bahwa penggunaan media pembelajaran sangat penting membantu atau mempermudah siswa untuk mendapatkan berbagai informasi termasuk konsep matematika. Studi kasus dalam penelitian ini mengatakan bahwa siswa masih menganggap matematika sebagai pelajaran yang abstrak atau sulit dipahami, siswa masih belum bisa menggambarkan visual dari konsep-konsep matematika. Oleh karena itu guru perlu menggunakan media pembelajaran sebagai alat bantu tercapainya konsep matematika yang diajarkan. Tentunya pengembangan media tersebut harus bersifat terbarui dan mengikuti perkembangan zaman, media yang dimaksud tersebut adalah smartphone.

Smartphone adalah suatu perangkat pintar yang di dalamnya terdapat berbagai bahasa komputasi yang memungkinkan untuk memasukkan algoritma matematika (Ismanto, Novalia and Herlandy, 2017; Nur, 2018). Smartphone dapat dikembangkan sesuai dengan kebutuhan untuk tercapainya tujuan pembelajaran. Penelitian yang dilakukan di MAN 1 Kota Pekalongan pada kelas X mengatakan bahwa sebagian besar siswa sudah tidak asing lagi dengan media smartphone. Smartphone digunakan sebagai kebutuhan khusus dalam berkomunikasi dan berbagai keperluan lainya, smartphone juga dapat dimanfaatkan sebagai media pembelajaran. Pemilihan smartphone sebagai media pembelajaran melalui beberapa tahapan analisis kebutuhan. Smartphone memiliki struktur yang baik, memiliki kelebihan dalam penggunaan sebagai media pembelajaran. Smartphone memiliki fungsi komputerisasi, pengiriman pesan dan akses terhubung keberbagai pengguna internet (Nugraha, 2017). Didalam smartphone dikembangkan sebuah aplikasi pembelajaran. Aplikasi tersebut didesain sesuai kebutuhan siswa dalam pembelajaran yang dapat memfasilitasi kemampuan berpikir kreatif siswa.

Permasalahan lain yang dialami oleh siswa adalah kemampuan berpikir kreatif matematis siswa yang rendah. Kemampuan berpikir kreatif menjadi faktor penting untuk menyelesaikan berbagai permasalahan khususnya matematika. Berpikir kreatif merupakan suatu proses di mana siswa dapat berpikir secara cepat, terarah, beralasan dan reflektif untuk menghasilkan suatu penyelesaian yang efektif. Berpikir kreatif merupakan kemampuan tingkat tinggi (high order thinking skill) yaitu proses berpikir yang memerlukan beberapa tahapan dalam menyelesaikan suatu permasalahan. Berpikir kreatif adalah kebiasaan tingkah laku berpikir yang dilatih dengan memperhatikan sudut pandang berbeda, memberikan imajinasi kepada siswa, mengungkapkan dengan kemungkinan-kemungkinan baru, membuka suatu sudut pandang yang berbeda dan menemukan ide-ide yang tidak terduga (Fitrina, Ikhsan and Munzir, 2016; Suripah and Sthephani, 2017). Kemampuan berpikir kreatif memiliki korelasi dengan perkembangan era modern. 
Penggunaan media pembelajaran dapat diimplementasikan dengan model pembelajaran yang ada. Model pembelajaran tersebut harus bersifat terbuka dan mengikuti perkembangan zaman, model pembelajaran yang digunakan adalah problem-based learning (PBL) (Wardono et al., 2016; Surya, 2017). PBL adalah suatu metode pengajaran yang digerakkan oleh suatu permasalahan berpusat pada siswa, masalah tersebut berkaitan dengan permasalahan dunia nyata yang tidak terstruktur diselesaikan oleh siswa di hadapan fasilitator atau tutor guru. Siswa bertanggung jawab untuk belajar mendapatkan berbagai informasi dan bekerja sama dengan orang lain, kemudian mengidentifikasikan informasi yang diketahui dan tidak diketahui untuk memecahkan suatu permasalahan. Namun penggunaan PBL masih memiliki beberapa kelemahan, yaitu fasilitas dan pemanfaatan media yang sangat berpengaruh terhadap berbagai informasi yang didapatkan oleh siswa. Permasalahan dari PBL adalah rancangan struktur pembelajaran pada tiap sekolah tidak dapat memfasilitasi berjalanya PBL (Sulistiyoningsih and Artikel, 2015; Putra et al., 2016; Siagian, Saragih and Sinaga, 2019). Pengembangan media pembelajaran sebagai upaya untuk meningkatkan kemampuan berpikir kreatif matematis siswa. Faktor permasalahan tersebut menjadi bahasan penting dalam penelitian ini. Yaitu bagaimana cara mengembangkan media pembelajaran dan meningkatkan kemampuan berpikir kreatif matematis siswa di era modern ini.

\section{METODE}

Metode penelitian menggunakan desain campuran $\mathrm{RnD}$ (Research and Development) pengembangan model ADDIE terdapat lima tahapan yaitu (analisis, desan, development, implementasi dan evaluasi) yang dapat disesuaikan dengan kebutuhan pengembangan. Model addie adalah salah satu model yang paling umum digunakan dalam penelitian pengembangan. ADDIE memiliki desain kontruksional yang bertahap serta langkah yang efektif dalam pengembanganya, model tersebut menggunakan desain instruktural yang dapat mengembangkan konten apapun atau guru dapat membuat desain pembelajaran yang efesien dan efektif. ADDIE dapat digunakan di lingkungan manapun baik pembelajaran online maupun tatap muka (Ngussa, 2014). Tahapan model ADDIE dapat diulang tiap fasenya, yang memungkinkan dapat direvisi tiap fase penelitian. Evaluasi dari hasil pengembangan menggunakan pendekatan kuantitatif, data kuantitatif digunakan sebagai analisis kemampuan berpikir kreatif matematis siswa. Penelitian dilakukan di MAN 1 Kota pekalongan dengan mengambil dua sampel kelas X. Sampel kelas ekperimen menggunakan model PBL berbantuan aplikasi smartphone dan kelas kontrol menggunakan PBL dengan pendekatan diskusi kelas. Analisis data kuantitatif didapatkan dari uji kemampuan berpikir kreatif matemetis siswa. Instrumen yang digunakan dalam penelitian ini adalah angket penilaian media pembelajaran dan angket rancangan pembelajaran. Indikator ketercapaian dari penelitian ini adalah, (1) pengembangan media pembelajaran mendapatkan kategori baik (2) ratarata klasikal kemampuan berpikir kreatif kelas ekperimen lebih tinggi dari kelas kontrol. Desain model ADDIE dijelaskan pada Tabel 1. 
Tabel 1. Pengembangan Model ADDIE

\begin{tabular}{|c|c|c|}
\hline Tahapan & Kegiatan & Instrument \\
\hline Analisis & $\begin{array}{l}\text { Mengidentifikasi suatu permasalahan } \\
\text { dan kebutuhan }\end{array}$ & $\begin{array}{ll}\text { - } & \text { Analisis Kebutuhan } \\
\text { - } & \text { Analisis Media } \\
\text { - } & \text { Analisis Permasalahan }\end{array}$ \\
\hline Desain & \begin{tabular}{|lrr} 
Langkah & mendesain & media \\
pembelajaran & dan & rancangan \\
pembelajaran yang akan digunakan
\end{tabular} & \begin{tabular}{llr} 
- & \multicolumn{2}{l}{ Perangkat pembelajaran } \\
- & Instrument perangkat \\
& pembelajaran \\
- & Instrument \\
& pembelajaran \\
- & Instrument kemampuan \\
& berpikir kreatif matematis
\end{tabular} \\
\hline Development & $\begin{array}{l}\text { Mengembangkan dan memverifikasi } \\
\text { media pembelajaran }\end{array}$ & $\begin{array}{ll}\text { - } & \text { Membuat media } \\
\text { - } & \text { Validasi media } \\
\text { - } & \text { Validasi perangkat } \\
& \text { pembelajaran }\end{array}$ \\
\hline Implementasi & $\begin{array}{l}\text { Mempersiapkan lingkungan dan } \\
\text { mengimplementasikan } \\
\text { pembelajaran }\end{array}$ & $\begin{array}{l}\text { - Implementasi PBL dan } \\
\text { Media pembelajaran }\end{array}$ \\
\hline Evaluasi & $\begin{array}{l}\text { Menilai kualitas produk dan proses } \\
\text { pembelajaran sebelum dan sesudah } \\
\text { implementasi sesuai dengan tujuan } \\
\text { pembelajaran }\end{array}$ & $\begin{array}{ll}\text { - } & \text { Evaluasi media } \\
\text { pembelajaran } \\
\text { - } & \text { Evaluasi kemampuan } \\
\text { berpikir kreatif matematis } \\
\text { siswa }\end{array}$ \\
\hline
\end{tabular}

\section{HASIL DAN DISKUSI}

\section{Pengembangan Media Pembelajaran}

Penelitian ini menggunakan pengembangan model ADDIE (analisis desain develop implementasi dan evaluasi). Faktor yang menjadi kelebihan dari penggunaan model addie adalah langkah pengembangan yang dapat sekaligus diimplementasikan dengan metode pembelajaran lainnya. Metode yang digunakan untuk menerapkan media pembelajaran ini menggunakan problem-based learning perbantuan aplikasi smartphone (Nada A., 2015).

\section{Analisis}

Model penelitian pengembangan ADDIE pada tahapan pertama adalah melakukan analisis kebutuhan, analisis kelayakan serta analisis syarat ketersediaan media. Tahapan analisis adalah tahapan awal pengembangan media pembelajaran, analisis yang digunakan dalam mengembangkan media pembelajaran yaitu analisis kebutuhan dan analisis ketersediaan media. Pada tahapan analisis kebutuhan disesuaikan dengan materi dan kompetisi yang akan dicapai, sedangkan untuk analisis ketersediaan menyesuaikan dengan ketersediaan media atau media perantara yang sering dijumpai oleh siswa (Widyastuti and Susiana, 2019). Media pembelajaran yang dikembangkan sebaiknya tidak memberatkan siswa dan mudah digunakan oleh siswa, karena sifat dari media pembelajaran adalah mempermudah siswa untuk belajar. Analisis kebutuhan siswa kelas 10 pada materi trigonometri adalah diperlukannya suatu media yang dapat menyampaikan konsep dan membuat visual dari materi trigonometri. Sedangkan untuk analisis ketersediaan media pembelajaran diambil dari media yang sering digunakan siswa, yang 
bersifat umum atau sering dijumpai oleh siswa. Media tersebut dapat menyampaikan konsep trigonometri yang bersifat abstrak atau sulit divisualkan oleh imajinasi siswa, dari analisis tersebut maka diambilah media smartphone sebagai media pembelajaran yang dikembangkan. Smartphone sebagai media modern yang dapat dirancang dengan bahasa komputasi matematika sehingga memudahkan untuk menampilkan konsep-konsep materi trigonometri, kemudian smartphone menjadi media yang sering dijumpai oleh siswa.

Tahapan analisis kemudian dikembangkan dengan kemampuan siswa, tahapan yang dilakukan adalah menganalisis kompetensi yang harus dikuasai oleh siswa, termasuk analisis pemilihan materi, modul dan berbagai sumber belajar siswa. Analisis karakteristik siswa terkait dengan pengetahuan, sikap, dan ketrampilan. Rangkuman dari hasil analisis tersebut kemudian di olah melalui beberapa tahapan reduksi data.

\section{Desain}

Tahapan desain adalah tahapan perencanaan pengembangan media pembelajaran. Pada tahapan desain berhubungan dengan tujuan pembelajaran, instrumen penelitian, konten isi media pembelajaran dan analisis perancangan media pembelajaran. Tujuan pengembangan media pembelajaran untuk memfasilitasi kemampuan berpikir kreatif matematis siswa, sehingga diperlukan aplikasi yang dapat memfasilitasi kemampuan berpikir kreatif dengan berbagai konsep. Aplikasi didesain dengan simbolsimbol yang sederhana yang memudahkan siswa menggunakan aplikasi tersebut. Didalam aplikasi terdapat berbagai materi trigonometri baik animasi maupun handbook buku paket, Aplikasi dilengkapi dengan soal-soal pemecahan masalah yang bervariasi. Kemudian aplikasi tersebut diberi nama AMAT (aplikasi matematia).

Pada tahapan desain peneliti merancang instrument penilaian untuk ahli media dan ahli materi. Untuk instrument media pembelajaran penilaian meliputi; Kesesuaian media dengan karakteristik media lingkungan, kemudahan pengoperasian media, tampilan media. Untuk instrument materi meliputi; Rancangan pembelajaran, isi materi, lembar kerja siswa. Aplikasi didesain dengan konsep-konsep materi trigonometri. Flowchart pengembangan media pembelajaran pada Gambar 1:

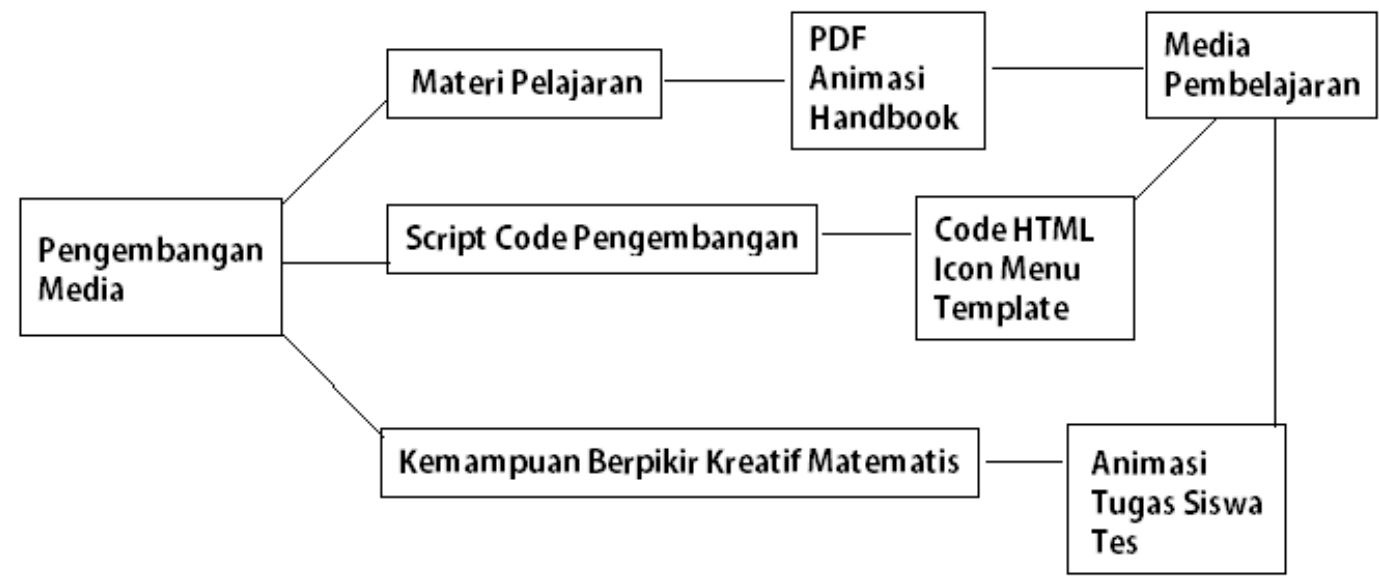

Gambar 1. Flowchart Pengembangan Media 
Pengembangan Media Pembelajaran Berbasis Aplikasi Smartphone Untuk Memfasilitasi Kemampuan Berpikir Kreatif Matematis Siswa, Yuyun Suria Priangga

\section{Development}

Pada tahapan development dilakukan perincian serta pengintegrasian teknologi atau media pembelajaran dengan isi materi pembelajaran. Tahapan development terdapat tiga tujuan utama yaitu mengembangkan isi materi pembelajaran, menyusun media pembelajaran yang terintegrasi dengan materi, dan penilaian dari tujuan media pembelajaran dan kemampuan berpikir kreatif matematis siswa (Nada A., 2015). (1) desain awal pada langkah development adalah membuat sampel faktual untuk desain pembelajaran, mengumpulkan berbagai sumber data yang relavan untuk pengembangan. (2) mengembangkan materi khusus, membuat ilustrasi dari konsep-konsep materi trigonometri, mendesain soal kemampuan berpikir kreatif, dan mengembangkan aplikasi. Pengembangan media pembelajaran menggunakan Bahasa HTML (Hypertext Markup Language) dan berbagai animasi yang dibuat sangat sederhana sehingga dapat diinstal di berbagai smartphone (android). (3) tahapan akhir development adalah meninjau kembali aplikasi dengan evaluasi hasil dari penilaian ahli materi dan ahli media. Berikut tampilan media pembelajaran pada Gambar 2.

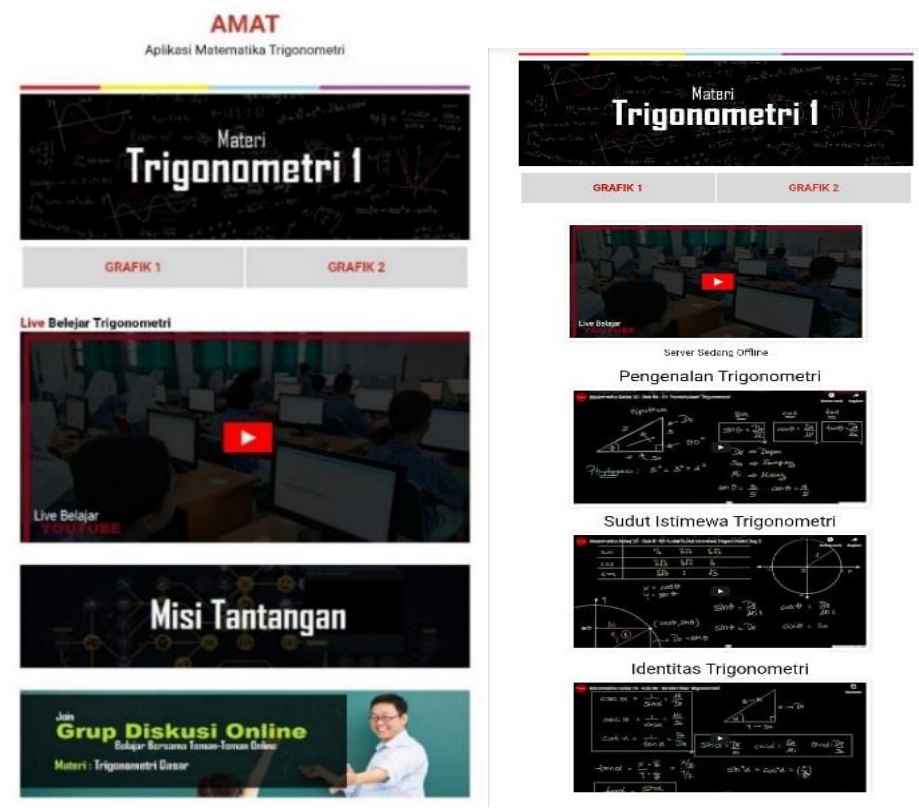

Gambar 2. Tampilan Media Pembelajaran

\section{Implementasi}

Tahapan implementasi adalah tahapan menjalankan penelitian atau program yang telah disusun sebelumnya, implementasi media pembelajaran dilakukan pada kelompok kecil terlebih dahulu untuk mendapatkan evaluasi yang mencangkup penilaian efektivitas, daya tarik, dan efisiensi media pembelajaran. Langkah utama yaitu mempersiapkan media pembelajaran, mengatur lingkungan atau tempat penelitian dan mempersiapkan siswa atau kegiatan belajar. Kegiatan implementasi adalah mempersiapkan kebutuhan siswa, mulai dari tempat kelas, media pembelajaran, buku materi dan lembar soal. Peneliti memastikan kegiatan berjalan dengan lancar tanpa kendala, peneliti mempersiapkan kegiatan secara detail. Hasil dari implementasi pada kelas kecil menjadi bahan evaluasi pengembangan. Tiap fase yang memiliki kekurangan akan dioptimalkan sesuai dengan kebutuhan pengembangan. 
Setelah mendapatkan hasil baik dari implementasi kelas kecil, kemduian media pembelajaran di implementasikan pada kelas besar atau kelas penelitian, Menurut (Nasution and Surya, 2017) langkah implementasi penelitian ini menggunakan model Problem-Based Learning berbantuan aplikasi smartphone pada Tabel 2:

Tabel 2. Kegiatan Implementasi Model Pembelajaran

\begin{tabular}{|l|l|l|}
\hline No & \multicolumn{1}{|c|}{ Fase } & \multicolumn{1}{c|}{ Kegiatan } \\
\hline 1. & Orientasi permasalahan & $\begin{array}{l}\text { Menjelaskan tujuan dari permasalahan, menjelaskan berbagai } \\
\text { informasi yang diperlukan, dan memberikan memotivasi } \\
\text { kepada siswa untuk dapat menyelesaikan }\end{array}$ \\
\hline 2. & $\begin{array}{l}\text { Mengorganisasi siswa untuk } \\
\text { belajar }\end{array}$ & $\begin{array}{l}\text { Membantu siswa menyelesaikan tugas belajar yang terkait } \\
\text { dengan masalah tersebut }\end{array}$ \\
\hline 3. & $\begin{array}{l}\text { Membimbing pengalaman } \\
\text { individu/ kelompok }\end{array}$ & $\begin{array}{l}\text { Mendorong siswa untuk mengumpulkan berbagai informasi } \\
\text { yang dibutuhkan, melaksanakan eksperimen, dan mencari } \\
\text { penjelasan dan solusi }\end{array}$ \\
\hline 4. & $\begin{array}{l}\text { Mengembangkan dan } \\
\text { menyajikan hasil karya }\end{array}$ & $\begin{array}{l}\text { Membantu siswa dalam merencanakan dan menyiapkan } \\
\text { berbagai bahan untuk dipersentasikan dan membantu mereka } \\
\text { untuk berbagi tugas dengan temannya }\end{array}$ \\
\hline 5. & $\begin{array}{l}\text { Menganalisis dan } \\
\text { mengevaluasi proses } \\
\text { pemecahan masalah }\end{array}$ & $\begin{array}{l}\text { Membantu siswa mengevaluasi dan mendiskusikan proses } \\
\text { penyelidikan yang mereka gunakan dalam menyelesaikan } \\
\text { masalah. }\end{array}$ \\
\hline
\end{tabular}

\section{Evaluasi}

Tahapan evaluasi adalah tahapan untuk mengetahui penilaian dan perbaikan dari media pembelajaran yang dikembangkan. Pada tahapan ini memastikan bahwa tiap langkah pengembangan ADDIE mencapai tujuan pengembangan. Terdapat dua penilaian evaluasi dalam penelitian ini, yaitu evaluasi penilaian formatif dan sumatif. Evaluasi penialai formatif digunakan untuk mengetahui hasil dari serangkaian kegiatan pengembangan yang dilakukan selama proses pembelajaran. Sedangkan evaluasi penilaian sumatif adalah penilaian yang focus terhadap hasil suatu target ketercapaian siswa. Ada tiga dasar proses evaluasi formatif yaitu, evaluasi pengembangan, evaluasi kelompok kecil, dan uji coba dilapangan.

Evaluasi Pengembangan, pada langkah ini evaluasi dilakukan untuk mengetahui apakah pengembangan media pembelajaran efektif terhadap kebutuhan siswa, kemudian mengidentifikasi kelebihan dan kekurangan pengembangan media pembelajaran. Jika dilihat dari hasil peneleitian, pengembangan ini sangat efektif dan efesien dalam penggunaan media pembelajaran yang mengandung unsur simpel atau mudah digunakan. Media yang dikembangkan dapat memuat berbagai konsep yang tidak dapat dijelaskan secara langsung. Langkah-langkah pengembangan telah sesuai dengan analisis kebutuhan dan ketersediaan barang.

Evaluasi Kelompok Kecil, melakukan kegiatan evaluasi dari ujicoba kelompok kecil. Tahapan ini mengevaluasi efektivitas penggunaan media pembelajaran dengan ketercapaian materi pelajaran. Ujicoba dilakukan oleh beberapa siswa serta ahli pengembangan media dan ahli materi pembelajaran. Hasil dari evaluasi kelompok kecil mengatakan bahwa isi media pembelajaran dan materi pelajar 
mendapat kategori penilaian baik, atau media pembelajaran dapat dikembangkan dan diuji cobakan pada penelitian.

Evaluasi Formatif, digunakan untuk mengevaluasi pengembangan dari hasil uji coba lapangan atau kelompok penelitian. Setelah implementasi media pembelajaran, dapat dikataka bahwa implementasi media pembelajaran menunjukan hasil yang baik, langkah pengembangan media pembelajaran yang baik dan terstruktur, proses implementasi media pembelajaran jelas, dan penilaian untuk ahli media dan ahli materi menunjukan hasil yang baik. Atau dapat disimpulkan pengembangan media pembelajaran sudah berjalan dengan baik. Berikut hasil penilaian pengembangan media pembelejaran dijelaskan pada Tabel 3.

Table 3. Hasil Validasi Instrumen

\begin{tabular}{|c|l|l|l|}
\hline No & Instrumen & Validator & Keterangan \\
\hline 1 & Silabus & V1 & Sangat Baik \\
& & V2 & Sangat Baik \\
& & V4 & Baik \\
\hline 2 & RPP, Materi dan & V1 & Sangat Baik \\
& Lembar Kerja & V2 & Sangat Baik \\
& & V4 & Baik \\
\hline 3 & Soal Kemampuan & V1 & Baik \\
& Berpikir Kreatif & V4 & Baik \\
\hline 4 & Media & V3 & Sangat Baik \\
& Pembelajaran & V2 & Sangat Baik \\
\hline
\end{tabular}

Evaluasi Sumatif, adalah evaluasi penilaian ketercapainya pengembangan media pembelajaran terhadap tujuan pengembangan. Tujuan pengembangan penelitian ini adalah memfasilitasi kemampuan berpikir kreatif matematis siswa. Hasil dari evaluasi sumatif membantu melihat nilai tujuan pengembangan. Evaluasi menggunakan data kuantitatif yang didapatkan dari tes terhadap kemampuan berpikir kreatif matematis siswa.

\section{Kemampuan Berpikir Kreatif Matematis Siswa}

Menurut (Sudianto, Dwijanto and Dewi, 2019) Berpikir kreatif adalah suatu respon menemukan sebuah solusi dengan berbagai strategi atau metode untuk menyelesaikan suatu permasahalan dengan caranya sendiri. Analisis kemampuan berpikir kreatif matematis siswa didapatkan dari mengolah hasil tes kemampuan berpikir kreatif siswa. Penilaian terhadap kemampuan berpikir kreatif menggunakan empat aspek; kelancaran, keluwesan, elaborasi, dan keorisinilan. Menurut Munandar menguraikan berpikir kreatif secara rinci sebagai berikut:

1.) Kelancaran memecahkan masalah, siswa dapat menyelesaikan permasalahan dengan memberikan banyak saran atau melakukan berbagai hal yang memberikan jawaban lebih dari satu jawaban.

2.) Kelenturan, siswa dapat menyelesaikan permasahalan dari sudut pandang yang berbeda, mencari banyak alternatif penyelesaian dan mampu mengubah cara pendekatan atau berpikir untuk menyelesaikan permasalahannya.

3.) Keaslian, siswa mampu melahirkan ungkapan yang baru dan unik, memikirkan beberapa cara yang 
tak lazim dengan jawaban lainya dan mampu membuat kombinasi-kombinasi untuk menyelesaikan suatu permasalahanya.

4.) Elaborasi, siswa mampu memperkaya dan mengembangkan suatu gagasan atau produk, menambahkan atau memberikan rincian secara detail dari suatu objek, gagasan atau situasi sehingga siswa dapat menyajikanya secara lebih menarik (Fitrina, Ikhsan and Munzir, 2016; Putra et al., 2016; Abidin, Rohaeti and Afrilianto, 2018).

Setiap aspek memiliki penilaian maksimal 4 dan minimal 0 , kemudian dibuat rata-rata kemampuan berpikir kreatif matematis tiap kelas ditunjukan pada Tabel 4.

Tabel 4. Rata-rata Kemampuan Berpikir Kreatif matematis Siswa

\begin{tabular}{|l|l|l|}
\hline & Kelas Ekperimen & Kelas Kontrol \\
\hline Rata-Rata & 71,18 & 54,12 \\
\hline \multicolumn{2}{|c}{ * Dalam skala 100}
\end{tabular}

Rata-rata kemampuan berpikir kreatif matematis siswa kelas ekperimen lebih tinggi dari pada siswa kelas kontrol. Siswa kelas ekperimen menerapkan model PBL berbantuan aplikasi smartphone mendapatkan rata-rata 71,18 lebih tinggi dari pada kelas kontrol menerapkan model PBL dengan pendekatan diskusi grup.

\section{KESIMPULAN}

Berdasarkan hasil pembahasan penelitian maka disimpulkan (1) pengembangan media pembelajaran menggunakan model ADDIE (analisis, desain, development, implementasi, evaluasi) mendapatkan kategori baik pada tiap instrumen penilaian. Dapat dikatakan bahwa media tersebut layak digunakan. (2) Kemudian hasil analisis rata-rata kemampuan berpikir kreatif matematis siswa kelas ekperimen lebih tinggi dari pada rata-rata kelas kontrol. Simpulan dari penelitian ini dapat menjadi acuan sebagai referensi pengembangan media pembelajaran yang dapat memfasilitasi kemampuan berpikir kreatif matematis siswa.

\section{REFERENSI}

Abidin, J., Rohaeti, E. E. and Afrilianto, M. (2018) 'Analisis Kemampuan Berfikir Kreatif Matematis Siswa Smp Kelas Viii Pada Materi Bangun Ruang', JPMI (Jurnal Pembelajaran Matematika Inovatif), 1(4), p. 779. doi: 10.22460/jpmi.v1i4.p779-784.

Fitrina, T., Ikhsan, M. and Munzir, S. (2016) 'Peningkatan Kemampuan Berpikir Kreatif dan Komunikasi Matematis Siswa SMA melalui Model Pembelajaran Project Based Learning Berbasis Debat', Jurnal Didaktik Matematika, 3(1), pp. 87-95. doi: 10.24815/jdm.v3i1.4753.

Ismanto, E., Novalia, M. and Herlandy, P. B. (2017) 'Pemanfaatan Smartphone Android Sebagai Media Pembelajaran Bagi Guru Sma Negeri 2 Kota Pekanbaru', Jurnal Pengabdian UntukMu NegeRI, 1(1), pp. 42-47. doi: 10.37859/jpumri.v1i1.33.

Nada A. (2015) 'ADDIE Model Nada', American International Journal of Contemporary Research 
ADDIE, 5(6), pp. 68-72.

Nasution, N. R. and Surya, E. (2017) 'Penerapan Model Pembelajaran Berbasis Masalah (Problem Based Learning) Terhadap Kemampuan Berpikir Kreatif Matematika Siswa', 1(1), pp. 98-102. Available at: http://semnastafis.unimed.ac.id.

Ngussa, B. M. (2014) 'Application of ADDIE Model of Instruction in Teaching-Learning Transaction among Teachers of Mara Conference Adventist Secondary Schools, Tanzania’, Journal of Education and Practice, 5(25), pp. 1-11.

Nugraha, A. I. (2017) 'Faktor-faktor yang mempengaruhi penggunaan smartphone dalam aktivitas belajar mahasiswa teknologi pendidikan universitas negeri yogyakarta', E-Jurnal Prodi Teknologi Pendidikan, 7(3), pp. 267-282.

Nur, A. (2018) ‘Mobile technology in a mathematics trail program: how does it works?', Unnes Journal of Mathematics Education, 7(1), pp. 24-30. doi: 10.15294/ujme.v7i1.21955.

Putra, R. D. et al. (2016) 'Peningkatan Kemampuan Berpikir Kreatif Siswa melalui Model Pembelajaran Inkuiri Terbimbing pada Siswa Kelas XI MIA 1 SMA Negeri Colomadu Karanganyar Tahun Pelajaran 2015 / 2016 The Increasing of Students Creative Thinking Ability Through of Inquiry Learni', Proceeding Biology Education Conference, 13(1), pp. 330-334.

Siagian, M. V., Saragih, S. and Sinaga, B. (2019) 'Development of Learning Materials Oriented on Problem-Based Learning Model to Improve Students' Mathematical Problem Solving Ability and Metacognition Ability', International Electronic Journal of Mathematics Education, 14(2), pp. 331-340. doi: 10.29333/iejme/5717.

Sudianto, Dwijanto and Dewi, N. R. (2019) 'Students' Creative Thinking Abilities and Self Regulated Learning on Project-Based Learning with LMS Moodle', Unnes Journal of Mathematics Education Research, 8(1), pp. 10-17. Available at: https://journal.unnes.ac.id/sju/index.php/ujmer/article/view/27183.

Sulistiyoningsih, T. and Artikel, I. (2015) 'Pbl Bernuansa Adiwiyata Dengan Blended Learning Untuk Meningkatkan Kemampuan Pemecahan Masalah Dan Karakter Peduli Lingkungan', Unnes Journal of Mathematics Education Research, 4(2), pp. 84-92.

Suripah, S. and Sthephani, A. (2017) 'Kemampuan berpikir kreatif matematis mahasiswa dalam menyelesaikan akar pangkat persamaan kompleks berdasarkan tingkat kemampuan akademik', Pythagoras: Jurnal Pendidikan Matematika, 12(2), pp. 149-160. doi: 10.21831/pg.v12i2.16509.

Surya, Y. F. (2017) 'Penerapan Model Pembelajaran Problem Based Learning untuk Meningkatkan Hasil Belajar Matematika Siswa Kelas IV SDN 016 Langgini Kabupaten Kampar', Jurnal Pendidikan Matematika, 1(1), pp. 38-53. Available at: https://bit.ly/2MXn3xs.

Wardono et al. (2016) 'Mathematics Literacy on Problem Based Learning with Indonesian Realistic Mathematics Education Approach Assisted E-Learning Edmodo', Journal of Physics: Conference Series, 693(1). doi: 10.1088/1742-6596/693/1/012014.

Widyastuti, E. and Susiana (2019) 'Using the ADDIE model to develop learning material for actuarial 
mathematics', Journal of Physics: Conference Series, 1188(1). doi: 10.1088/17426596/1188/1/012052. 